\title{
sciendo
}

\section{EFFECTS OF FEEDING UREA-TREATED TRITICALE AND OAT GRAIN MIXTURES ON RUMINAL FERMENTATION, MICROBIAL POPULATION, AND MILK PRODUCTION PERFORMANCE OF MIDLACTATION DAIRY COWS*}

\author{
Kacper Libera ${ }^{1,2}$, Malgorzata Szumacher-Strabel ${ }^{1}$, Mina Vazirigohar ${ }^{3}$, Wiktor Zieliński ${ }^{1}$, Rafal Lukow ${ }^{4}$, \\ Klaudia Wysocka ${ }^{4}$, Pawel Kołodziejski ${ }^{5}$, Dorota Lechniak ${ }^{6}$, Zora Varadyova ${ }^{7}$, Amlan Kumar Patra ${ }^{8}$, \\ Adam Cieslak ${ }^{1 *}$
'Department of Animal Nutrition, Poznan University of Life Sciences, Wołyńska 33, 60-637 Poznań, Poland
${ }^{2}$ Department of Preclinical Sciences and Infectious Diseases, Poznan University of Life Sciences, Wołyńska 35, 60-637, Poznań, Poland
${ }^{3}$ Zist Dam Group, University Incubator Center, University of Zanjan, Zanjan 45371-38791, Iran
${ }^{4}$ Barbatus Ltd., Przemysława 3, 62-081 Baranowo, Poland
${ }^{5}$ Department of Animal Physiology, Biochemistry and Biostructure, Poznan University of Life Sciences, Wołyńska 35, 60-637 Poznań, Poland
${ }^{6}$ Department of Genetics and Animal Breeding, Poznan University of Life Sciences, Wołyńska 33, 60-637 Poznań, Poland
${ }^{7}$ Department of Digestive Tract Physiology, Institute of Animal Physiology, Soltesovej 4-6, 040-01 Kosice, Slovakia
${ }^{8}$ Department of Animal Nutrition, West Bengal University of Animal and Fishery Sciences, 37 K. B. Sarani, Kolkata, India
•Corresponding author: adam.cieslak@up.poznan.pl

\begin{abstract}
The starch content of triticale and oat grains provides much of their readily available energy. Synchronizing energy and nitrogen in the rumen is important in optimizing profitability; for this reason, ammonia processing of these grains was evaluated for its potential to modify ruminal fermentation and to improve milk production performance. A mixture of ground triticale and oats (CONG, at a ratio of 60:40 on a dry matter basis) was treated with urea $(5 \mathrm{~kg} / 1000 \mathrm{~kg})$ and urease additive (20 kg/1000 kg) containing $200 \mathrm{~g} / \mathrm{kg}$ of moisture, for $2 \mathrm{wk}$ (UREG). The urea treatment enhanced the $\mathrm{pH}$ and $\mathrm{CP}$ content of grains by $34 \%$ and $52 \%$, respectively. In a batch culture study, CONG or UREG as the only substrate was incubated in a buffered ruminal fluid. Compared to CONG, UREG increased $\mathrm{pH}$, total VFA concentration, total gas, and disappearance of DM, while reducing $\mathrm{CH}_{4}$ production, whereas $\mathrm{NH}_{3}$ concentration increased and entodiniomorph counts tended to increase. In the in vivo study, cows were randomly allocated to two dietary groups $(n=24)$ and were offered TMR based on maize and grass silage, containing either $155 \mathrm{~g} / \mathrm{kg}$ of CONG and $80 \mathrm{~g} /$ $\mathrm{kg}$ of soybean meal (CONT) or $155 \mathrm{~g} / \mathrm{kg}$ of UREG and $59 \mathrm{~g} / \mathrm{kg}$ of soybean meal (URET) for $31 \mathrm{~d}$.
\end{abstract}

*This research was conducted with the support of statutory funding from the Faculty of Veterinary Medicine and Animal Science, Poznań University of Life Science, Poland, from the Department of Animal Nutrition (no. 506.533.04.00). 
Ruminal fluid was collected $(n=10)$ using rumenocentesis. The relative abundances of Streptococcus bovis decreased, but Megasphaera elsdenii, methanogens, and ammonia-producing bacteria increased by URET. Entodiniomorph and holotrich counts were decreased by URET. Feeding with URET increased ruminal pH and concentrations of total VFA, acetate, branched-chain VFA, and $\mathrm{NH}_{3}$. Feeding with URET also increased milk yield. These results demonstrate that replacing untreated triticale and oat grains with urea-treated grains can beneficially modulate ruminal microbiota and fermentation, consequently improving production performance and profitability.

Key words: dairy cow, milk, ammoniation, grain, ruminal fermentation

Triticale and oat grains are widely produced and commonly fed to lactating dairy cows in many countries. According to the Food and Agriculture Organization of the United Nations, 16 million tonnes of triticale grains and 26 million tonnes of oat grains were produced worldwide in 2017 (FAOSTAT, 2017). A significant proportion of the starch in these grains (more than $800 \mathrm{~g} / \mathrm{kg}$ ) is degradable by ruminants (Humer and Zebeli, 2017). In diets containing triticale and oats, especially as the sole source of grains, partial substitution of true protein (i.e., soybean meal) with nonprotein nitrogen (NPN), such as feed grade urea, may result in better synchronization of energy and protein content, improvements in microbial protein synthesis in the rumen, and minimization of $\mathrm{N}$ excretion to the environment (Golombeski et al., 2006; Sinclair et al., 2012). However, the hydrolysis of feed grade urea to ammonia in the rumen is very rapid, which can override its utilization by ruminal microbes, leading to ammonia toxicity and wastage of feed N (Patra and Aschenbach, 2018). Ammoniation processing of grains, in which the grains are exposed to moisture and urea (Humer and Zebeli, 2017), can allow ammonia to be slowly released into the rumen (Nikulina et al., 2018); additionally, replacing a high cost $\mathrm{N}$ source with a low cost $\mathrm{N}$ source with expected similar $\mathrm{N}$ release may contribute to increased dairy farm profitability. Cereal grains are usually ground before feeding to dairy cattle; however, inclusion in the diet of large proportions of ground grains - especially those providing large amounts of starch that rapidly degrades in that rumen, like triticale - might lead to ruminal fermentation disorders and reduce productivity. Ammoniation of grains can decrease ruminal starch degradation (Humer and Zebeli, 2017). Moreover, the $\mathrm{pH}$ of urea-treated grains increases (Hannukkala and Huhtanen, 1986), which provides an alkalizer to improve ruminal function.

Limited information is available on the effects of a mixture of urea-treated triticale and oat grains on lactating cow performance. Previous studies have mainly been limited to evaluating ammonia-treated barley, with some oats; the majority of these studies used steers (Ørskov et al., 1980; Low and Kellaway, 1983). Moreover, we used the 60:40 ratio because triticale is more often used in cow nutrition than oat grain in Poland. The evaluation of a urea-treated mixture of triticale and oat grain in dairy cows is thus relevant. The ruminal microbial ecosystem is a critical factor that links diets to bovine physiology and productivity. We hypothesized that replacing untreated grains and some soybean meal with urea-treated grains in the diets of lactating dairy cows may favorably modify ruminal microbiota composition and fermentation, and thus improve milk production performance. The objective of this 
study was thus to examine the effects of feeding urea- and urease-treated triticale and oat grains on in vitro and in vivo ruminal fermentation characteristics, selected microbial populations, milk production, and milk composition of midlactation dairy cows. The cost of feeding was also taken into account.

\section{Material and methods}

The effects of a mixture of ground triticale and oat grains treated with urea was investigated in two successive experiments: an in vitro ruminal fermentation experiment and an in vivo experiment to evaluate production performance, ruminal fermentation, and selected microbial populations in lactating cows. All experiments were conducted in accordance with the guidelines of the Local Ethical Commission for Investigations on Animals and Polish law.

\section{Urea treatment of grains}

A mixture of ground triticale and ground oats, at a ratio of 60:40 on a dry matter (DM) basis, was prepared as the control untreated grains (CONG). To prepare the urea-treated grains (UREG), each $1000 \mathrm{~kg}$ of CONG grains was mixed with urea (15 $\mathrm{kg} / 1000 \mathrm{~kg}$ CONG on a DM basis; Rumisan feed-grade urea; Yara, Grimsby, UK) and urease $(5 \mathrm{~kg} / 1000 \mathrm{~kg}$ CONG on a DM basis; Maxammon; Harbro, Turriff, Aberdeenshire, UK) in the mixer wagon; water $(70 \mathrm{~L} /$ tonne $)$ was added to obtain a total moisture content of $200 \mathrm{~g} / \mathrm{kg}$. The mixture was tightly covered with a plastic sheet to avoid ammonia release and stored for two weeks in a warehouse. The chemical composition of CONG and UREG is presented in Table 1.

Table 1. Ingredients and chemical composition of control (CONT) and urea-treated grains (URET) diets as well as control untreated grains (CONG) and urea-treated grains

\begin{tabular}{|c|c|c|c|c|}
\hline \multirow{2}{*}{ Item } & \multicolumn{2}{|c|}{ Diets } & \multicolumn{2}{|c|}{ Grains } \\
\hline & CONT & URET & CONG & UREG \\
\hline 1 & 2 & 3 & 4 & 5 \\
\hline \multicolumn{5}{|l|}{ Ingredients (g/kg of DM) } \\
\hline maize silage & 367 & 376 & - & - \\
\hline grass silage & 190 & 196 & - & - \\
\hline $\mathrm{CONT}^{1}$ & 155 & - & - & - \\
\hline URET $^{2}$ & - & 155 & - & - \\
\hline beet pulp & 106 & 110 & - & - \\
\hline extracted soybean meal & 80 & 59 & - & - \\
\hline extracted rapeseed meal & 40 & 41 & - & - \\
\hline dried distillers' grains with solubles & 31 & 32 & - & - \\
\hline barley straw & 18 & 18 & - & - \\
\hline mineral and vitamin premix ${ }^{3}$ & 13 & 13 & - & - \\
\hline
\end{tabular}


Table $1-$ contd.

\begin{tabular}{|c|c|c|c|c|}
\hline 1 & 2 & 3 & 4 & 5 \\
\hline \multicolumn{5}{|c|}{ Chemical composition ( $\mathrm{g} / \mathrm{kg}$ of DM or as indicated) } \\
\hline $\mathrm{DM}(\mathrm{g} / \mathrm{kg})$ & 420 & 408 & 895 & 828 \\
\hline $\mathrm{OM}$ & 909 & 929 & 972 & 978 \\
\hline $\mathrm{CP}$ & 129 & 133 & 99.5 & 151 \\
\hline $\mathrm{NDF}^{4}$ & 349 & 359 & 235 & 240 \\
\hline $\mathrm{ADF}$ & 214 & 238 & 92.7 & 94.1 \\
\hline starch & 254 & 248 & 602 & 550 \\
\hline VEM $^{5}$ & 978 & 970 & - & - \\
\hline $\mathrm{pH}$ & - & - & 6.37 & 8.53 \\
\hline
\end{tabular}

${ }^{1}$ Contained (DM basis) a mixture of ground triticale and oat grains (60:40).

${ }^{2}$ Contained a mixture of ground triticale and oat grains (60:40) treated with urea and urease additive.

${ }^{3}$ Declared to contain (g/kg of DM) Na (123), Ca (100), Mg (45), P (42), K (20), S (18), Co (14), Cu (5.0), Zn (2.8), Mn (1.4), Fe (1.05), F (0.42), I (0.028), Se (0.018), biotin (0.008); (IU/kg), vitamin A (200,000), vitamin $\mathrm{D}_{3}(40,000)$, and vitamin $\mathrm{E}(1,200)$.

${ }^{4} \mathrm{NDF}=$ aNDFom, amylase- and sodium sulfite-treated NDF corrected for ash residue.

${ }^{5} \mathrm{VEM}=$ feed unit net energy lactation; calculated using the FeedExpert software.

\section{Experimental design, treatments, management, and sample collection}

In vitro

Fresh ruminal inoculum was collected at the slaughterhouse from six Polish Holstein-Friesian dairy cows (two cows in each run). The cows were fed the same control total mixed ration (TMR) used in the in vivo experiment (Table 1). Ruminal content (approximately $600 \mathrm{~g}$ ) from each cow was collected from the top, bottom, and middle parts of the rumen. The ruminal content of each cow was separately squeezed through 4 layers of cheesecloth into a bottle (Schott, Elmsford, NY, USA), and quickly transported under anaerobic conditions to the laboratory. The in vitro procedure was performed as previously described by Szumacher-Strabel et al. (2011). Briefly, $400 \mathrm{mg}$ (DM basis) samples of CONG or UREG as substrates were weighed directly in 125-mL glass incubation bottles (Midland Scientific, Omaha, NE, USA). The ruminal fluid was diluted with a buffer solution at a ratio of 1:4, and $40 \mathrm{~mL}$ of buffered rumen fluid was transferred into the incubation bottles containing substrate. The bottles were then filled with $\mathrm{CO}_{2}$, closed with a rubber stopper, sealed with aluminum covers, and incubated anaerobically in an incubator (Galaxy 170R; Eppendorf North America, Hauppauge, NY, USA) at $39^{\circ} \mathrm{C}$ and periodically agitated for $24 \mathrm{~h}$ of incubation. The experiment was conducted in three separate runs on different days, including two control blank bottles (containing buffered rumen fluid only) and three incubation bottles for each substrate per run. All fermentation characteristics and protozoa counts were determined after $24 \mathrm{~h}$ of fermentation. For protozoa measurement, a 1-mL portion of fermented fluid sample was preserved using $6 \mathrm{~mL}$ of $4 \%$ formalin, and stored at room temperature in the dark until enumeration. 


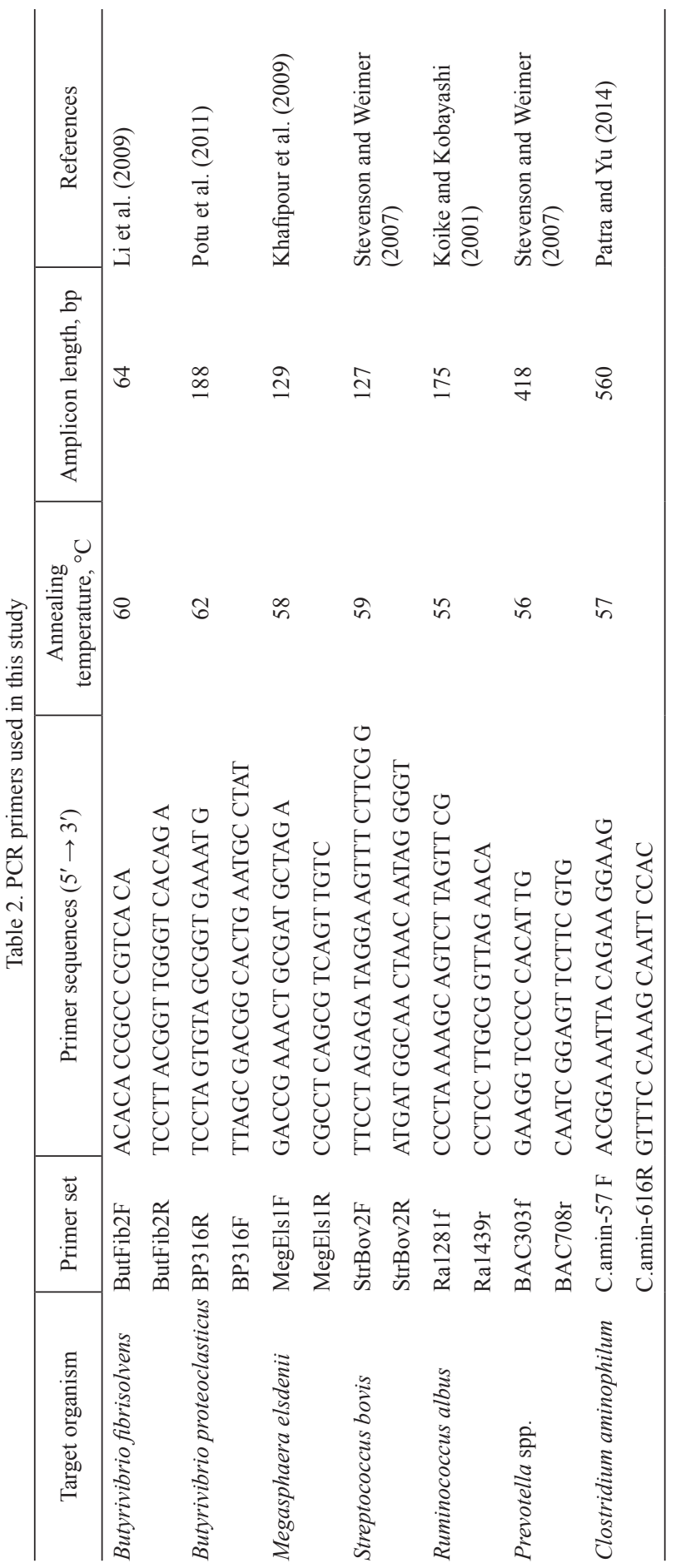




\section{In vivo}

The in vivo experiment was carried out on a commercial dairy farm (Młynek, Greater Poland voivodeship, Poland) from May to June 2019. Forty-eight multiparous Polish Holstein-Friesian lactating dairy cows $(580 \pm 40 \mathrm{~kg}$ body weight; 5-6 month of lactation; $28.5 \pm 0.8 \mathrm{~kg} / \mathrm{d}$ of milk production) were randomly allocated to two dietary groups (24 animals in each group with similar milk production). The feeding period lasted for $31 \mathrm{~d}$. In the control group (CONT) TMR consisted of maize and grass silage (2:1 w/w; ca. 60:40 forage:concentrate ratio) and $155 \mathrm{~g} / \mathrm{kg}$ of CONG and $80 \mathrm{~g} / \mathrm{kg}$ of soybean meal. In the experimental group (URET), TMR consisted of maize and grass silage $(2: 1 \mathrm{w} / \mathrm{w}$; ca. 60:40 forage:concentrate ratio) and $155 \mathrm{~g} / \mathrm{kg}$ of UREG and $59 \mathrm{~g} / \mathrm{kg}$ of soybean meal. The CONG or UREG was used as the sole grain source in the TMR. The TMRs were formulated using FeedExpert software (Rovecom; Hoogeveen, The Netherlands) with similar N and net energy content (Table 1). In order to avoid the confounding effects of DM intake, the feeding schedule was designed as described by van Zijderveld et al. (2011). The daily DM intake was maintained at $21.8 \pm 0.4 \mathrm{~kg} / \mathrm{cow}$ per day during the experiment, with some modifications. Briefly, fresh TMR was offered daily as equal meals at 06:00 and 18:00 h. During the first $20 \mathrm{~d}$ of the experiment, the cows were fed TMR ad libitum. From day 20 onwards, the cows were provided TMR restricted to $95 \%$ of the average daily voluntary DM intake, based on days 15 to 20 of the cows assigned to each treatment. Drinking water was offered ad libitum. Cows were milked twice daily at 05:30 and 17:30 h. Samples of fresh TMR and grains were collected four times a week and immediately delivered to the laboratory for analysis.

Daily milk production was measured using a milk meter (WB Ezi-Test Meter $33 \mathrm{~kg}$; True-Test, Manukau, New Zealand). Milk samples without preservatives were collected at each milking from all cows on days 29 and 30 of the experiment, and directly analyzed for fat, $\mathrm{CP}$, lactose, and urea. Ruminal fluid was collected from ten randomly selected animals in each group on day 31 (the last day of experiment), $3 \mathrm{~h}$ after morning feeding, using rumenocentesis, as described by Nordlund and Garrett (1994). Ruminal fluid was collected by a veterinarian during the routine ruminal acidosis monitoring procedure carried out on the farm. Immediately after collection (20 $\mathrm{mL}$ sample), $\mathrm{pH}$ was determined, and a $10-\mathrm{mL}$ aliquot of the filtered ruminal fluid was stored at $-80^{\circ} \mathrm{C}$ until analysis of fermentation parameters (ammonia and VFA) and bacterial populations. Additionally, a 1-mL aliquot of ruminal fluid sample was preserved using $6 \mathrm{~mL}$ of formalin solution $(40 \mathrm{~mL} / \mathrm{L})$ and stored until the protozoa were counted. The chemical composition of CONT and URET is presented in Table 1.

\section{Laboratory analysis}

Samples of TMRs and grains were analyzed following the procedures of AOAC (2007) for DM (method no. 934.01), ash (method no. 942.05), and CP (using a KjelFoss Automatic 16210 analyzer; AISN Foss Electric, Denmark; method no. 976.05). The concentration of NDF in feeds was determined using heat-stable $\alpha$-amylase and sodium sulfite on a Fibertec System (Foss Tecator, Höganäs, Sweden) and reported on an ash-free basis. The starch content was determined using the polarimetric method, following Polish Standard PN-R-64785:1994, using a polarimeter (AP-300; Ata- 
go, Japan). Milk samples were analyzed for basic milk constituents using an infrared analyzer (Milko-Scan 255 A/S N; Foss Electric, Hillerød, Denmark). The urea concentration in the milk was determined using an infrared spectrometer (CombiFoss 6000 analyzer; Foss Electric, Hillerød, Denmark).

Ruminal $\mathrm{pH}$ was determined immediately after sample collection using a $\mathrm{pH}$ meter (CP-104; Elmetron, Zabrze, Poland). Ammonia concentration was measured following a colorimetric Nessler method described previously by Szumacher-Strabel et al. (2011). The VFA concentrations and in vitro dry matter digestibility (IVDMD) were determined following a procedure described by Szumacher-Strabel et al. (2011). Briefly, $1 \mu \mathrm{L}$ of prepared sample was injected into a GC (Varian CP 3380; Sugarland, TX, USA) equipped with an injector at $220^{\circ} \mathrm{C}$, a flame-ionization detector at $230^{\circ} \mathrm{C}$, and a capillary column $(30 \mathrm{~m} \times 0.25 \mathrm{~mm}$; Agilent HP-Innowax, 19091N-133, Agilent Technologies, Santa Clara, CA). The oven temperature was set at $130^{\circ} \mathrm{C}$. Hydrogen was used as a carrier gas at a flow rate of $25 \mathrm{~mL} / \mathrm{min}$. The VFA peaks were quantified by MS Work Station 5.0 using an external standard prepared by mixing individual VFA (Sigma Aldrich, St. Louis, MO, USA).

After $24 \mathrm{~h}$ of in vitro fermentation, the total gas from each bottle was collected by a calibrated Hohenheim 100-mL gas-tight syringe (Häberle Labortechnik, LonseeEttlenschieß, Germany) fitted with a needle to a rubber stopper on the fermentation bottle. For methane concentration in vitro, at the same time, $500 \mu \mathrm{L}$ of gas sample was collected from the headspace of each bottle (Gastight syringes, Hamilton Bonaduz, Switzerland). Methane concentration was analyzed by a GC (SRI PeakSimple model 310; Alltech, State College, PA, USA) equipped with a thermal conductivity detector and Carboxen-1000 column (mesh side 60/80, 15 FT $\times 1.8$ INS.S, Supelco, Bellefonte, PA, USA), appropriate gas standards (mix gases of $5.63 \% \mathrm{CO}_{2}, 5.56 \%$ $\mathrm{CH}_{4}, 5.10 \% \mathrm{H}_{2}$, and the rest $\mathrm{N}_{2}$; Multax, Zielonki-Parcela, Poland), and PeakSimple version 3.29, following Szumacher-Strabel et al. (2011). For the determination of IVDMD, the contents of each incubation bottle at $24 \mathrm{~h}$ of fermentation were transferred to previously weighed crucibles. The residues were thoroughly washed with distilled water and dried at $105^{\circ} \mathrm{C}$ for $3 \mathrm{~d}$. The percentage loss in weight of the feed DM through microbial fermentation process was expressed as IVDMD. Methane production in vivo was estimated based on theoretical stoichiometry of rumen molar proportions of individual VFA in the rumen, following Wolin (1960). The ciliate protozoa were counted microscopically (150×; Zeiss Primo Star no. 5; Carl Zeiss Microscopy, Jena, Germany); 10 and $100 \mu \mathrm{L}$ of ruminal fluid was used for counting entodiniomorphs and holotrichs, respectively. Each sample was counted twice. The results were then converted considering the dilutions used. DNA extraction was performed following Yu and Morrison (2004) using a QIAamp DNA Stool Mini Kit (Qiagen; Hilden, Germany). DNA quality was evaluated using electrophoresis on a $1 \%(\mathrm{~W} / \mathrm{V})$ agarose gel and DNA quantity was measured using a NanoDrop ND1000 spectrophotometer (Thermo Scientific; Wilmington, USA). The DNA samples were stored at $-20^{\circ} \mathrm{C}$ until analysis. Seven target taxa and selected bacteria species (namely Prevotella spp., Clostridium aminophilum, Megasphaera elsdenii, Streptococcus bovis, Butyrivibrio proteoclasticus, Butyrivibrio fibrisolvens, and Ruminococcus albus) were quantified by qPCR (QuantStudio 12K Flex Real-Time PCR 
System; Applied Biosystems, Warrington, Cheshire, UK) following the procedure described by Patra and Yu (2014). Samples were analyzed in triplicate for each taxon, and a negative control was included in each run. The primer sequences that were used for the PCR reaction were obtained from the literature and are given in Table 2. Moreover, the specificity of primers was confirmed using the primer-BLAST program in the GenBank Database. The PCR reaction protocol consisted of an initial denaturation step (at $95^{\circ} \mathrm{C}$ for $10 \mathrm{~min}$ ), followed by 45 cycles of $95^{\circ} \mathrm{C}$ for $15 \mathrm{~s}$ and annealing step (at the temperature indicated for the primer pair for $30 \mathrm{~s}$ ), and a final elongation step (at $70^{\circ} \mathrm{C}$ for $30 \mathrm{~s}$ ). Melting curve analysis was performed after PCR reaction to verify the specificity of the PCR amplification $\left(0.1^{\circ} \mathrm{C} / \mathrm{s}\right.$ increment from $65^{\circ} \mathrm{C}$ to $95^{\circ} \mathrm{C}$ with fluorescence collection at $0.1^{\circ} \mathrm{C}$ intervals). Additionally, verification of product size was performed by gel electrophoresis of samples after the PCR run. The relative abundance of each taxon was calculated according to the cycle threshold method [2- $\Delta \mathrm{Ct}=2-(\mathrm{Ct}$ taxon $-\mathrm{Ct}$ reference $)]$, as described by Schmittgen and Livak (2008).

Methanogens (all methanogens: S-D-Arch-0915-a-A-20, and two order-specific probes: S-O-Mmic-1200-a-A-21 (Methanomicrobiales) and SF-Mbac-0310-a-A-22 (Methanobacteriales)) and total bacteria were quantified by fluorescence in situ hybridization (FISH), following Józefiak et al. (2013), with some modifications. Briefly, $50 \mu \mathrm{L}$ of rumen fluid was diluted in phosphate-buffered saline (PBS) and pipetted onto $0.22 \mathrm{~m}$ polycarbonate filters (Frisenette K02BP02500) and vacuumed (Vacuum KNF Vacuport-Neuberg). After vacuuming, the filters were transferred onto cellulose disks for dehydration in an ethanol series (50\%, 80\%, and 90\%, 3 min each). For each sample, a series of identical filters were prepared to allow the determination of optimal hybridization. Hybridizations were carried out in $50 \mu \mathrm{L}$ of hybridization buffer (0.9 M NaCl; $20 \mathrm{mM}$ Tris/HCl, pH 7.2; 0.01\% SDS) containing oligonucleotide probes (all methanogens (S-D-Arch-0915-a-A-20) and two order-specific probes: S-O-Mmic-1200-a-A-21 (Methanomicrobiales) and SF-Mbac-0310-a-A-22 (Methanobacteriales) (Soliva et al., 2004). After hybridization, the filters were washed with washing buffer (20 mM Tris/HCl, pH 7.2; 0.01\% SDS; 5 mM EDTA) for $20 \mathrm{~min}$ at $48^{\circ} \mathrm{C}$. The filters were rinsed gently in distilled water, air-dried, and mounted on object glasses with VectaShield anti-fading agent (Vector laboratories no. H-1000) containing DAPI (4,6-diamidino-2-phenylindole). To distinguish the total count of bacteria (DAPI) from other methanogens in the rumen fluid, filters were maintained at $4^{\circ} \mathrm{C}$ for $1 \mathrm{~h}$ in the dark until visualized using an Axio Imager M2 microscope (Carl Zeiss Iberia, Madrid, Spain).

\section{Feed cost calculation}

FeedExpert software (Rovecom, Hoogeveen, Netherlands) was used to calculate the cost of feeding the dairy cows. This cost was calculated based on the actual prices paid during the in vivo experiment. It was assumed that the prices of urea, urease additive, and soybean meal were around $€ 0.837, € 4.80$, and $€ 0.33$ per $\mathrm{kg}$, respectively.

\section{Statistical analysis}

Data from the in vitro experiment were obtained only at one-time point (at $24 \mathrm{~h}$ of incubation) for each replicate. Data were analyzed in one-way ANOVA us- 
ing Sigma Plot software (version 11.0). Data from in vivo experiment were analyzed with a model that included the fixed effect of dietary treatment and the random effect of cows within the group using JMP software (SAS Institute). Least squares means are reported and the effects of treatments were taken to be significant at $\mathrm{P}<0.05$, and tendencies at $0.05 \leq \mathrm{P} \leq 0.10$. Statistically significant differences between bacteria stains in CONT and URET group were analyzed using the unpaired Student $t$-test (two-tailed distribution) or the Mann-Whitney $U$-test, if the data were not normally distributed. Statistical significance was defined as $\mathrm{P}<0.05$.

\section{Results}

\section{Chemical composition of grains and diets and cost of diets}

Chemical analysis of the grains showed greater $\mathrm{pH}$ and $\mathrm{CP}$ concentration in UREG than in CONG (Table 1). Chemical composition was similar for both TMRs (Table 1). The cost of untreated and urea-treated grains was $€ 0.147$ and $€ 0.170 / \mathrm{kg}$, respectively. Overall, the daily cost of the URET diet was lower (mainly due to there being $0.5 \mathrm{~kg} / \mathrm{d}$ per cow less extracted soybean meal) than that of the CONT diet (€3.01 vs. €3.19/d, respectively).

\section{In vitro experiment}

Higher $(\mathrm{P}<0.05) \mathrm{pH}$ and concentrations of ammonia and total VFA were observed in the UREG compared with the CONG (Table 3). The greater concentration of total VFA for UREG grains was due to the increased $(\mathrm{P}<0.05)$ acetate, propionate, valerate, isovalerate, and isobutyrate concentrations (Table 3 ). However, the butyrate concentration and the acetate:propionate ratio were similar $(\mathrm{P}>0.10)$ for both grains. Total gas production increased $(\mathrm{P}<0.01)$ for the UREG compared with the CONG. However, methane concentration was reduced $(\mathrm{P}<0.01)$ by approximately $4 \%$ in the UREG and a lower proportion of methane to total gas production $(\mathrm{P}<0.01)$ was also observed in the UREG than in the CONG grains (Table 3). The IVDMD increased $(\mathrm{P}<0.01)$ with the processing of grains with urea. The in vitro total protozoa population tended $(\mathrm{P}=0.06)$ to increase with the UREG, compared with the CONG, with a tendency $(\mathrm{P}=0.06)$ for an increase in the number of entodiniomorphs (i.e., more than $99 \%$ of total protozoa count) (Table 3 ).

\section{In vivo experiment}

Ruminal $\mathrm{pH}$ and concentrations of ammonia and total VFA were greater $(\mathrm{P}<0.05)$ in cows fed the URET diet than in those fed the CONT diet (Table 4). The increases in the total VFA concentration in the rumen of cows fed the URET diet were due to increases $(\mathrm{P}<0.05)$ in the concentrations of acetate, isobutyrate, and isovalerate. The ratios of acetate to propionate and (acetate + butyrate) to propionate increased $(\mathrm{P}<0.05)$ with the feeding of URET TMR to dairy cows. Total protozoa, entodiniomorph, and holotrich populations decreased $(\mathrm{P}<0.05)$ in the rumen with the replacement of CONG with UREG in the diet of dairy cows. 
Table 3. Effects of urea-treated grains on ruminal fermentation characteristics and microbial counts after 24 h incubation in vitro $(\mathrm{n}=18)$

\begin{tabular}{|c|c|c|c|c|}
\hline \multirow{2}{*}{ Item } & \multicolumn{2}{|c|}{ Treatment $^{1}$} & \multirow{2}{*}{ SEM } & \multirow{2}{*}{ P-value } \\
\hline & CONG & UREG & & \\
\hline $\mathrm{pH}$ & 6.19 & 6.26 & 0.010 & $<0.01$ \\
\hline Ammonia (mM ) & 16.0 & 17.3 & 0.38 & 0.02 \\
\hline \multicolumn{5}{|l|}{ VFA (mM) } \\
\hline total VFA & 43.4 & 49.1 & 1.68 & $<0.01$ \\
\hline acetate (A) & 26.2 & 29.9 & 1.33 & $<0.01$ \\
\hline propionate $(\mathrm{P})$ & 11.1 & 13.0 & 0.56 & $<0.01$ \\
\hline butyrate (B) & 4.43 & 4.23 & 0.230 & 0.86 \\
\hline valerate & 0.64 & 0.80 & 0.029 & $<0.01$ \\
\hline isovalerate & 0.72 & 0.82 & 0.023 & $<0.01$ \\
\hline isobutyrate & 0.33 & 0.36 & 0.034 & 0.01 \\
\hline $\mathrm{A}: \mathrm{P}$ ratio & 2.45 & 2.34 & 0.138 & 0.96 \\
\hline$(\mathrm{A}+\mathrm{B}): \mathrm{P}$ ratio & 2.86 & 2.84 & 0.159 & 0.88 \\
\hline \multicolumn{5}{|l|}{ Gas production } \\
\hline Total gas (mL/g of incubated DM) & 293 & 295 & 0.73 & $<0.01$ \\
\hline Methane (mmol/g of incubated DM) & 2.41 & 2.32 & 0.015 & $<0.01$ \\
\hline $\mathrm{CH}_{4} /$ total gas $(\mathrm{mmol} / \mathrm{L})$ & 7.57 & 7.24 & 0.05 & $<0.01$ \\
\hline IVDMD (g/kg) & 604 & 644 & 8.1 & 0.01 \\
\hline \multicolumn{5}{|l|}{ Protozoa $\left(\times 10^{5} / \mathrm{mL}\right)$} \\
\hline total & 2.52 & 2.95 & 0.136 & 0.06 \\
\hline entodiniomorphs & 2.49 & 2.91 & 0.135 & 0.06 \\
\hline holotrichs & 0.035 & 0.036 & 0.0028 & 0.71 \\
\hline
\end{tabular}

${ }^{1} \mathrm{CONG}(\mathrm{DM}$ basis $)=$ a mixture of ground triticale and oat grains $(60: 40)$; UREG (DM basis) = a mixture of ground triticale and oat grains (60:40) treated with urea $(15 \mathrm{~g} / \mathrm{kg})$ and urease additive $(5 \mathrm{~g} / \mathrm{kg})$ containing 200 $\mathrm{g} / \mathrm{kg}$ of moisture.

Feeding URET diet increased $(\mathrm{P}<0.05)$ yields of milk, milk protein, and milk lactose, and tended $(\mathrm{P}=0.05)$ to increase milk fat production compared with CONT (Table 5). Fat and lactose concentrations in milk were not affected $(\mathrm{P}>0.10)$, whereas protein concentration tended $(\mathrm{P}=0.06)$ to increase and urea concentration increased $(\mathrm{P}<0.01)$ with feeding URET.

The abundances of Prevotella spp., M. elsdenii, and B. proteoclasticus increased $(\mathrm{P}<0.05)$, while $C$. aminophilum tended to increase $(\mathrm{P}=0.06)$ in the rumen of cows fed the URET diet, compared with the CONT diet (Figure 1). The abundances of $B$. fibrisolvens and $R$. albus in the rumen were not affected $(\mathrm{P}>0.10)$, whereas $S$. bovis decreased $(\mathrm{P}<0.05)$ with feeding URET (Figure 1). The abundance of total bacteria was significantly higher in the cows fed the URET diet than in those receiving the CONT diet (Table 4). The abundance of total methanogens was significantly higher $(\mathrm{P}=0.03)$ in the CONT group than in the URET group. However, no differ- 
ences $(\mathrm{P}>0.10)$ were found in the abundance of Methanobacteriales and Methanomicrobiales between the treatments (Table 4).

Table 4. Effects of replacing untreated grains and a part of soybean meal with urea-treated grains in the diets of midlactation cows $(n=10)$ on ruminal fermentation characteristics and protozoa numbers

\begin{tabular}{|c|c|c|c|c|}
\hline \multirow{2}{*}{ Item } & \multicolumn{2}{|c|}{ Treatment $^{1}$} & \multirow{2}{*}{ SEM } & \multirow{2}{*}{ P-value } \\
\hline & CONT & URET & & \\
\hline $\mathrm{pH}$ & 5.66 & 5.98 & 0.049 & $<0.01$ \\
\hline Ammonia (mM) & 10.6 & 14.7 & 0.85 & 0.01 \\
\hline \multicolumn{5}{|l|}{ VFA (mM) } \\
\hline total VFA & 95.6 & 110 & 2.38 & 0.02 \\
\hline acetate $(\mathrm{A})$ & 51.7 & 63.3 & 1.57 & $<0.01$ \\
\hline propionate $(\mathrm{P})$ & 23.5 & 24.6 & 0.79 & 0.49 \\
\hline butyrate (B) & 14.9 & 16.0 & 0.34 & 0.18 \\
\hline valerate & 3.02 & 2.74 & 0.084 & 0.10 \\
\hline isobutyrate & 1.03 & 1.27 & 0.053 & 0.03 \\
\hline isovalerate & 1.45 & 1.89 & 0.072 & $<0.01$ \\
\hline $\mathrm{A}: \mathrm{P}$ ratio & 2.29 & 2.62 & 0.081 & 0.04 \\
\hline$(\mathrm{A}+\mathrm{B}): \mathrm{P}$ ratio & 2.87 & 3.24 & 0.089 & 0.04 \\
\hline $\begin{array}{l}\text { Methane }(\mathrm{mmol} / \mathrm{mol} \text { of } \\
\text { VFA) }\end{array}$ & 0.58 & 0.47 & 0.014 & $<0.01$ \\
\hline Total bacteria $\left(\times 10^{8} / \mathrm{mL}\right)$ & 119 & 127 & 3.3 & $<0.01$ \\
\hline \multicolumn{5}{|l|}{ Methanogens $\left(\times 10^{8} / \mathrm{mL}\right)$} \\
\hline total & 33.1 & 5.76 & 2.06 & 0.03 \\
\hline Methanobacteriales & 20.2 & 4.43 & 0.82 & 0.87 \\
\hline Methanomicrobiales & 45.6 & 5.02 & 2.68 & 0.45 \\
\hline \multicolumn{5}{|l|}{ Protozoa $\left(\times 10^{5} / \mathrm{mL}\right)$} \\
\hline total & 5.32 & 3.97 & 0.281 & 0.01 \\
\hline entodiniomorphs & 5.27 & 3.94 & 0.279 & 0.02 \\
\hline holotrichs & 0.046 & 0.030 & 0.0027 & $<0.01$ \\
\hline
\end{tabular}

${ }^{1}$ CONT $(\mathrm{DM}$ basis $)=\mathrm{a}$ TMR based on maize and grass silage $(2: 1 \mathrm{w} / \mathrm{w} ; \mathrm{ca} .60: 40$ forage:concentrate ratio) containing $155 \mathrm{~g} / \mathrm{kg}$ of CONG and $80 \mathrm{~g} / \mathrm{kg}$ of soybean meal; URET (DM basis) = a TMR based on maize and grass silage (2:1 w/w; ca. 60:40 forage:concentrate ratio) containing $155 \mathrm{~g} / \mathrm{kg}$ of CONG and $59 \mathrm{~g} / \mathrm{kg}$ of soybean meal.

Table 5. Effects of replacing untreated grains and a part of soybean meal with urea-treated grains in the diets of midlactation cows $(n=24)$ on milk production and composition

\begin{tabular}{l|c|c|c|c}
\hline \multirow{2}{*}{ Item } & \multicolumn{2}{|c|}{ Treatment $^{1}$} & \multirow{2}{*}{ SEM } & \multirow{2}{*}{ P-value } \\
\cline { 2 - 3 } & CONT & URET & & 5 \\
\hline Yield & 2 & 3 & 4 & 5 \\
milk $(\mathrm{kg} / \mathrm{d})$ & 27.6 & 29.4 & 0.36 & 0.01 \\
\hline
\end{tabular}


Table 5 - contd.

\begin{tabular}{lccccc}
\hline \multicolumn{1}{c|}{1} & 2 & 3 & 4 & 5 \\
\hline $\mathrm{FCM}^{\prime} \%(\mathrm{~kg} / \mathrm{d})$ & 31.1 & 32.7 & 0.98 & 0.40 \\
$\mathrm{ECM}^{2}(\mathrm{~kg} / \mathrm{d})$ & 25.5 & 27.7 & 0.31 & $<0.01$ \\
milk fat $(\mathrm{g} / \mathrm{d})$ & 1,002 & 1,076 & 19.2 & 0.05 \\
milk protein $(\mathrm{g} / \mathrm{d})$ & 837 & 937 & 12.8 & $<0.01$ \\
milk lactose $(\mathrm{g} / \mathrm{d})$ & 1,340 & 1,449 & 17.8 & $<0.01$ \\
Composition $(\mathrm{g} / \mathrm{kg})$ & 25.5 & 27.6 & 0.32 & $<0.01$ \\
milk fat & 36.6 & 36.7 & 0.74 & 0.96 \\
milk protein & 30.5 & 31.9 & 0.38 & 0.06 \\
milk lactose & 49.2 & 48.7 & 0.20 & 0.18 \\
milk urea $(\mathrm{mmol} / \mathrm{L})$ & 2.91 & 4.06 & 0.12 & $<0.01$ \\
\hline
\end{tabular}

${ }^{1}$ CONT $(\mathrm{DM}$ basis $)=\mathrm{a}$ TMR based on maize and grass silage $(2: 1 \mathrm{w} / \mathrm{w}$; ca. $60: 40$ forage:concentrate ratio $)$ containing $155 \mathrm{~g} / \mathrm{kg}$ of CONG and $80 \mathrm{~g} / \mathrm{kg}$ of soybean meal; URET (DM basis) = a TMR based on maize and grass silage (2:1 w/w; ca. 60:40 forage:concentrate ratio) containing $155 \mathrm{~g} / \mathrm{kg}$ of CONG and $59 \mathrm{~g} / \mathrm{kg}$ of soybean meal.

${ }^{2}$ Energy-corrected milk yield calculated according to Sjaunja et al. (1990).

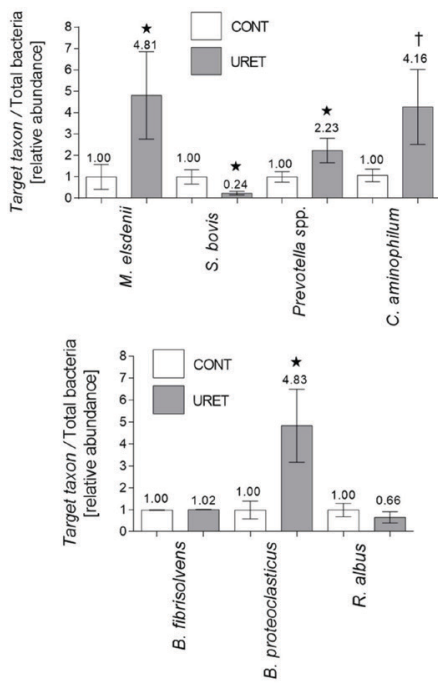

${ }^{1}$ CONT $(\mathrm{DM}$ basis $)=\mathrm{a}$ TMR based on maize and grass silage $(2: 1 \mathrm{w} / \mathrm{w}$; ca. $60: 40$ forage:concentrate ratio) containing $155 \mathrm{~g} / \mathrm{kg}$ of CONG and $80 \mathrm{~g} / \mathrm{kg}$ of soybean meal; URET (DM basis) = a TMR based on maize and grass silage $(2: 1 \mathrm{w} / \mathrm{w}$; ca. $60: 40$ forage:concentrate ratio) containing $155 \mathrm{~g} / \mathrm{kg}$ of CONG and $59 \mathrm{~g} / \mathrm{kg}$ of soybean meal. Bacteria species include Prevotella spp., Clostridium aminophilum, Megasphaera elsdenii, Streptococcus bovis, Butyrivibrio proteoclasticus, Butyrivibrio fibrisolvens, and Ruminococcus albus. ${ }^{*}$ and $\dagger$ indicate statistical significance at $\mathrm{P}<0.05$ and $0.05 \leq \mathrm{P} \leq 0.10$, respectively. Bars indicates standard error $(\mathrm{n}=10)$.

Figure 1. Effects of replacing untreated grains and part of the soybean meal with urea-treated grains in the diets of midlactation cows on the relative abundance of ruminal selected bacteria species (abundance of a target taxon relative to the reference value and then respective to the total bacteria) 


\section{Discussion}

Cereal grains constitute a major component of the diet of high-producing lactating dairy cows, and are the most important ingredient inducing ruminal fermentation perturbation and acidosis problems. The formulation of diets providing considerable amounts of readily available carbohydrates, while maintaining the ruminal $\mathrm{pH}$ in the physiological range to avoid ruminal acidosis (SARA) is essential for both nutritionists and dairy farmers. Researchers are also interested in alternative sources of protein because the European Union produces no more than one third of its total dietary protein demand (Kim et al., 2019). Feed-grade urea is an inexpensive feed additive that supplies soluble $\mathrm{N}$ for ruminal microbes; however, due to the rapid conversion of urea to ammonia in the rumen, and the potential associated problems, there is growing interest in slowing down the hydrolysis of urea in the rumen (Patra and Aschenbach, 2018).

\section{Chemical composition of grains}

In the present study, the treatment of a mixture of ground triticale and oat grains with urea and urease additive increased $\mathrm{pH}$ and $\mathrm{CP}$ concentration by approximately 34 and 52\%, respectively. Similar changes in the $\mathrm{pH}$ and $\mathrm{CP}$ content of whole barley grains under similar processing condition have been observed (Hannukkala and Huhtanen, 1986). Increases in $\mathrm{pH}$ values through urea treatment were greater in ground grains than in whole grains (Nikulina et al., 2018), and a range of 8-72 g/ $/ \mathrm{kg}$ increases in CP content has been reported for urea-treated grains (Humer and Zebeli, 2017).

\section{In vitro experiment}

Replacing CONG with UREG grains in vitro resulted in the modulation of ruminal fermentation, with increases in $\mathrm{pH}$, total VFA concentration, and IVDMD, and decreases in methane concentration. In the present experiment, the ammonia concentration in UREG grain was higher than in CONG after $24 \mathrm{~h}$ of incubation, due to the higher concentration of CP in UREG. However, it has been hypothesized that ammonia captured within a cellular matrix of urea-treated grains might be released more slowly than the free ammonia added to the diet in the form of feed-grade urea (Srivastava and Mowat, 1980). In a direct comparison (Nikulina et al., 2018) examining urea treatment of high-moisture barley in vitro, the $\mathrm{pH}$ of the fermentation fluid in urea-treated and urea-added grains were similar, but were greater than the untreated grains; urea-treated grains led to greater ammonia concentration than with the untreated grains, but lower ammonia concentration than with the urea-added grains during $8 \mathrm{~h}$ of incubation. It has been indicated that protozoa are responsible for degrading dietary and microbial protein, reducing microbial protein synthesis, and increasing ammonia production in the rumen (Firkins et al., 2007). The observed increases in the protozoal population with UREG can therefore also explain part of the greater accumulation of ammonia in UREG treatment.

Ruminal VFAs are derived mainly from dietary carbohydrate fermentation (Firkins, 1996); thus, a higher VFA concentration in UREG reflects greater fermentation 
of carbohydrates by urea processing. Because both treatments had approximately the same amounts of carbohydrate (as a substrate of fermentation), the response observed can mostly be attributed to the greater in vitro digestibility of DM. Increased ruminal ammonia levels have been shown to enhance DM digestibility (Wallace, 1979), due to increased enzymatic activity and growth of the microbial populations, particularly when nitrogen supply is limited, which is in agreement with the current experimental conditions where the available $\mathrm{N}$ increased in UREG compared with CONG grains. Several studies have also shown that ammoniation reduced the concentrations of hemicellulose, lignin, and cellulose (Lines et al., 1996), and improved the digestibility of fiber in forages (Schiere and de Wit, 1995). In the present experiment, increased total VFA concentration was due to the increased concentrations of acetate and propionate, suggesting greater digestion of NDF and starch, as well as valerate, isovalerate, and isobutyrate in the rumen. Ruminal branched short-chain VFA were primarily generated by bacterial deamination of some amino acids arising from dietary true protein degradation in the rumen, although microbial protein recycling also produces branched-chain VFA (Miura et al., 1980). The greater concentrations of isovalerate and isobutyrate can thus be explained by increased digestion of cell wall associated-true protein (extension proteins) in the ammoniated grains (Chalupa and Sniffen, 1991) as well as increases in dietary and microbial protein degradation by greater number of protozoa observed in the current study.

In the experiment described here, the number of protozoa increased, but the methane production decreased when UREG was used, suggesting that direct interference with the methanogen and protozoa population did not occur, and that a decrease might occur in the substrate available for methanogenesis through action on other rumen microorganisms. Similar to our findings, increasing urea supplementation from 0 to $20 \mathrm{~g} / \mathrm{kg}$ diet increased protozoa populations, but had no effect on methane after $24 \mathrm{~h}$ in vitro rumen fermentation (Zhang et al., 2016).

\section{In vivo experiment}

Due to availability of urea additive on the market at the time, the feeding period lasted 31 days. Our study thus had some limitations. Nevertheless, the ruminal fermentation results of the in vivo experiment in terms of $\mathrm{pH}$, ammonia, and total VFA were consistent with the in vitro experiment. The cows fed the URET diet had increased ruminal $\mathrm{pH}(+0.32)$, mostly attributable to the greater $\mathrm{pH}$ of the ammoniated grains and thus the alkalizing effects in the rumen and the slower degradation rate of starch. In the study of Benedeti et al. (2014), the replacement of soybean meal by slow-release urea in the high-concentrate diets of beef cattle allowed better recovery of ruminal $\mathrm{pH}$ after it had reached low values. The greater ruminal $\mathrm{pH}$ associated with the URET, rather than with the CONT diet, in this experiment also reflected on the lower abundance of S. bovis in the rumen. S. bovis has high amylolytic activity and often is associated with ruminal acidosis (Chow and Russell, 1990). Robinson and Kennelly (1989) reported that the declining rate of post-feeding ruminal $\mathrm{pH}$ progressively decreased as ammoniation levels of high-moisture barley increased; this response was attributed to the slower rate of starch degradation in the rumen. 
In the present experiment, cows fed the URET diet showed a greater concentration of ammonia than did cows fed the CONT diet, though both diets had similar CP content. Soybean meal partially replaced by a slow-release urea product lowered the concentration of ruminal ammonia in lactating cows fed a diet based on corn grains (Golombeski et al., 2006) or in beef cattle fed the high-concentrate diet (Benedeti et al., 2014). The responses of these studies exhibited a slow-release urea property (Huntington et al., 2006), and likely better ruminal synchrony of the available energy from the diet and $\mathrm{N}$ from slow-release urea (Golombeski et al., 2006). In the present study, the release of ammonia from the starch matrix was perhaps faster than the degradation rate of the soybean meal protein. In the present experiment, DM intake was kept constant at $22 \mathrm{~kg} / \mathrm{d}$ in both dietary groups. In previous studies, feeding ammoniated barley did not alter DM intake in lactating cows (Robinson and Kennelly, 1989) or feedlot steers (Bradshaw et al., 1996). However, Golombeski et al. (2006) reported a decrease in DM intake due to the replacement of soybean meal with slowrelease urea, and this response has been attributed, in part, to the bitter taste of urea. Cow's milk production increased with the URET in the present experiment. The positive effect of ammoniated grains on the total ruminal VFA concentration can explain the increased milk production.

In the present study, greater milk yield together with the lower daily cost of URET feeding would provide greater economic benefits to the farmers. Moreover, the yield of milk fat increased with the URET diet. This greater synthesis of milk fat might have resulted from the lower production of antilipogenic biohydrogenation intermediates in the rumen of cows fed the ammoniated grains, due to the increase in ruminal $\mathrm{pH}$ and decrease in the abundance of $S$. bovis and M. elsdenii (Rico et al., 2015). In agreement with our results, the addition of ammoniated grains in dairy rations (Robinson and Kennelly, 1989), or feeding with slow-release urea (Golombeski et al., 2006), increased milk fat production. The URET diet tended to increase milk protein concentration, which together with the greater milk yield, led to an increase in milk protein yield by the cows. The milk protein response in the current experiment can be attributed in part to the reduction in ruminal protozoa population, which might be associated with increases in the flow of amino acids (of feed and bacterial origin) into the duodenum, and thus the yield of milk protein (Firkins, 1996; Petit et al., 2005). Cows fed the URET diet exhibited higher milk urea concentrations due to the greater ruminal ammonia concentration. The replacement of true protein with slow-release urea also increased milk urea concentration (Sinclair et al., 2012), though not in all cases (Golombeski et al., 2006). In another study (Highstreet et al., 2010), the full replacement of feed-grade urea with slow-release urea did not alter milk urea concentration.

For molecular analysis, rumen fluid samples usually are collected from fistulated cows, which is a validated technique. However, in the present study, for both technical and animal-welfare reasons, we decided to collect rumen fluid via punction (rumenocentesis). This should be kept in mind in the following results and discussion.

In the current experiment, ruminal abundances of most of the selected taxa increased with the URET diet: B. proteoclasticus +4.83 , M. elsdenii +4.81 , and Prevo- 
tella spp. +2.23 . C. aminophilum tended to increase +4.16 with the URET diet. Subsequently, the total bacteria count was significantly higher with URET than with CONT. This greater complexity in the microbial population with the feeding of urea-treated grains can be attributed to the more stable ruminal environment. These responses can be attributed, at least in part, to the lowered protozoal population. The antiprotozoal effect would be beneficial in reducing the predation of bacteria by protozoa, therefore increasing the number of bacteria participating in ruminal fermentation and the amount of microbial protein that passes to the small intestine (Firkins, 1996). In the current experiment, the protozoa population and the abundance of total methanogens decreased in the rumen of cows fed the URET diet. Prevotella spp. are the dominant bacteria in the rumen (making up approximately half of the total bacteria) and have important roles in the degradation of feed, especially of fiber-rich diets (Stevenson and Weimer, 2007). This genus is the main group of rumen proteolytic and ammonia-producing microbes (Firkins et al., 2007), and one of the few groups reported to be involved in the degradation of oligopeptides into amino acids (Calsamiglia et al., 2010). C. aminophilum is one of the three well-documented hyperammonia-producing bacterial species (Firkins et al., 2007). In the current experiment, the increased abundances of Prevotella spp. and C. aminophilum with URET diet can be attributed, to some extent, to the greater protein digestibility in the rumen, which was in accordance with the observed greater rumen availability of proteolysis and products (isobutyrate, isovalerate, and ammonia).

$S$. bovis is a lactate-producing bacterium involved in lactic acidosis (Owens et al., 1998), while $M$. elsdenii is one of the few species able to utilize lactate (Palmonari et al., 2010). Consistent with the higher ruminal $\mathrm{pH}$ of cows fed the URET diet, a greater abundance of $M$. elsdenii and a lower abundance of $S$. bovis were observed with the URET diet.

\section{Conclusion}

We evaluated the potential of ammoniation of a mixture of triticale and oat grains in modulating ruminal fermentation in vitro, as well as milk production performance, ruminal fermentation, and selected microbial populations in vivo. The positive changes in ruminal fermentation parameters were reflected in the production performance indices. Feeding URET increased yields of milk, milk fat, milk protein, lactose, and urea concentrations. Higher milk yield, combined with the lower daily cost of feeding with URET, contribute to increased dairy farm profitability. Hence, reducing soybean meal content in the diet and replacing untreated grains with ureatreated grains in midlactation dairy cows can be economically advantageous.

\section{Conflicts of interest}

The authors declare that they do not have any conflicts of interest.

\section{References}

Association of Official Analytical Chemists (AOAC) (2007). Official Methods of Analysis (18th ed.), ed. by Horwitz W. and Latimer W., AOAC International, Gaithersburg, MD. 
Benedeti P.D., Paulino P.V., Marcondes M.I., Valadares Filho S.C., Martins T.S., L is bo a E.F., S ilva L.H., Te ix e ir a C.R., D u arte M.S. (2014). Soybean meal replaced by slow release urea in finishing diets for beef cattle. Livest Sci., 165: 51-60.

B rad shaw W.L., H in man D.D., Bull R.C., Ever s on D.O., S oren se n S.J. (1996). Effects of barley variety and processing methods on feedlot steer performance and carcass characteristics. J. Anim. Sci., 74: 18-24.

Calsamiglia S., Ferret A., Reynolds C.K., Kristensen N.B., Van Vuuren A.M. (2010). Strategies for optimizing nitrogen use by ruminants. Animal, 4: 1184-1196.

Chalupa W., Sn iffen C.J. (1991). Protein and amino acid nutrition of lactating dairy cattle. Vet. Clin. N. Am.-Food A., 7: 353-372.

Ch ow J.M., R u s s e 11 J.B. (1990). Effect of ionophores and pH on growth of Streptococcus bovis in batch and continuous culture. Appl. Environ. Microbiol., 56: 1588-1593.

FAOSTAT (2017). Food and agriculture data. Food and Agriculture Organization of the United Nations Statistics Division, Rome, Italy. Accessed Nov. 19, 2019.

F i r k i n s J.L. (1996). Altering ruminal nitrogen metabolism to improve protein utilization maximizing microbial protein synthesis in the rumen. J. Nutr., 126: 1347-1354.

F ir k in s J.L., Yu Z., M o r r i s o n M. (2007). Ruminal nitrogen metabolism: Perspectives for integration of microbiology and nutrition for dairy. J. Dairy Sci., 90: E1-E16.

Golombeski G.L., Kals cheur K.F., Hippen A.R., Schingoethe D.J. (2006). Slow-release urea and highly fermentable sugars in diets fed to lactating dairy cows. J. Dairy Sci., 89: 4395-4403.

Han nuk ka la A., H u h t a n en P. (1986). Urea treatment of barley grain. Effect on storage properties and fungal growth. Agr. Food Sci., 58: 197-208.

Highstreet A., Robinson P.H., Robison J., Garrett J.G. (2010). Response of Holstein cows to replacing urea with with a slowly rumen released urea in a diet high in soluble crude protein. Livest. Sci., 129: 179-185.

H u mer E., Z e beli Q. (2017). Grains in ruminant feeding and potentials to enhance their nutritive and health value by chemical processing. Anim. Feed Sci. Technol., 226: 133-151.

Hunt ington G.B., Harmon D.L., K r i sten sen N.B., Han s on K.C., S p e a r s J.W. (2006). Effects of a slow-release urea source on absorption of ammonia and endogenous production of urea by cattle. Anim. Feed Sci. Technol., 130: 225-241.

Józe fi a k D., K i e rońc zy k B., Juśk i ew i c z J., Z d uńc zy k Z., R a w s ki M., Dłu g o s z J., $\mathrm{S}$ i p A., Højberg O. (2013). Dietary nisin modulates the gastrointestinal microbial ecology and enhances growth performance of the broiler chickens. PLoS ONE, 8: 1-11.

Khafipour E., Li S., Plaizier J.C., Krause D.O. (2009). Rumen microbiome composition determined using two nutritional models of subacute ruminal acidosis. Appl. Environ. Microbiol., 75: 7115-7124.

K im S.W., Les s J.F., Wang L., Yan T., Kiron V., Ka ushik S.J., Le i X.G. (2019). Meeting global feed protein demand: challenge, opportunity, and strategy. Annu. Rev. Anim. Biosci., 7: 17.1-17.23.

K o i ke S., K o b a y a h i Y. (2001). Development and use of competitive PCR assays for the rumen cellulolytic bacteria: Fibrobacter succinogenes, Ruminococcus albus and Ruminococcus flavefaciens. FEMS Microbiol. Lett., 204: 361-366.

L i M., P enner G.B., Hern and e z-S a n a bri a E., O b a M., G u a n L.L. (2009). Effects of sampling location and time, and host animal on assessment of bacterial diversity and fermentation parameters in the bovine rumen. J. Appl. Microbiol., 107: 1924-1934.

L in e s L.W., K o c h M.E., We is s W.P. (1996). Effect of ammoniation on the chemical composition of alfalfa hay baled with varying concentrations of moisture. J. Dairy Sci., 79: 2000-2004.

L ow S., Kellaw ay R. (1983). The utilization of ammonia-treated whole wheat grain by young steers. Anim. Sci. J., 37: 113-118.

Mi ura H., Horiguchi M., Mats u moto T. (1980). Nutritional interdependence among rumen bacteria, Bacteroides amylophilus, Megaspaera elsdenii, and Ruminococcus albus. Appl. Environ. Microbiol., 40: 294-300.

Nikulina A., S a rn a t a ro C., F a bro C., M a s o n F., S pang h e ro M. (2018). In vitro ammonia release of urea-treated high moisture barley and maize grain. J. Anim. Feed Sci., 27: 173-178. 
Nordlund K.V., Garrett E.F. (1994). Rumenocentesis: a technique for collecting rumen fluid for the diagnosis of subacute rumen acidosis in dairy herds. The Bovine Practitioner, 28: $109-112$.

Ørskov E., Barnes B., Lukins B. (1980). A note on the effect of different amounts of $\mathrm{NaOH}$ application on digestibility by cattle of barley, oats, wheat and maize. J. Agric. Sci., 94: 271-273.

O we n s F.N., S e cris t D.S., Hill W.J., Gill D.R. (1998). Acidosis in cattle: a review. J. Anim. Sci., 76: $275-286$

P a 1 monari A., S teven son D.M., Merten s D.R., Cruywagen C.W., We i mer P.J. (2010). $\mathrm{pH}$ dynamics and bacterial community composition in the rumen of lactating dairy cows. J. Dairy Sci., 93: 279-287.

P a tr a A.K., A s c h e $\mathrm{n} b$ a ch J.R. (2018). Ureases in the gastrointestinal tracts of ruminant and monogastric animals and their implication in urea-N/ammonia metabolism: A review. J. Adv. Res., 13: $39-50$.

Patra A.K., Yu Z. (2014). Effects of vanillin, quillaja saponin, and essential oils on in vitro fermentation and protein-degrading microorganisms of the rumen. Appl. Microbiol. Biotechnol., 98: 897-905.

P e t i t H.V., I v a n M., M i r P.S. (2005). Effects of flaxseed on protein requirements and $\mathrm{N}$ excretion of dairy cows fed diets with two protein concentrations. J. Dairy Sci., 88: 1755-1764.

Potu R.B., Abu Ghazaleh A.A., Hasting s D., Jones K., Ibrahim S.A. (2011). The effect of lipid supplements on ruminal bacteria in continuous culture fermenters varies with the fatty acid composition. J. Microbiol., 49: 216-223.

Ri c o D.E., Prest on S.H., R is s e r J.M., H a r v a t in e K.J. (2015). Rapid changes in key ruminal microbial populations during the induction of and recovery from diet-induced milk fat depression in dairy cows. Brit. J. Nutr., 114: 358-367.

R o b in s o n P.H., K e n n elly J.J. (1989). Influence of ammoniation of, high-moisture barley on digestibility, kinetics of rumen ingesta turnover, and milk production in dairy cows. Can. J. Anim. Sci., 69: 195-203.

Schiere J.B., de Wit J. (1995). Feeding urea ammonia treated rice straw in the tropics. II. Assumptions on nutritive value and their validity for least cost ration formulation. Anim. Feed Sci. Technol., 51: 45-63.

$\mathrm{S} \mathrm{ch} \mathrm{m}$ it t $\mathrm{g}$ e $\mathrm{n}$ T.D., L i v a k K.J. (2008). Analyzing real-time PCR data by the comparative CT method. Nat. Protoc., 3: 1101-1108.

S in cla ir L.A., B la k e C.W., Griffin P., J on es G.H. (2012). The partial replacement of soyabean meal and rapeseed meal with feed grade urea or a slow-release urea and its effect on the performance, metabolism and digestibility in dairy cows. Animal, 6: 920-927.

S j a u n j a L.O., B a evre L., J unk karin en L., P edersen J. (1990). A Nordic proposal for an energy corrected milk (ECM) formula. 27th Session of ICRPMA, pp. 156-157.

Soliva C.R., M eile L., Ci es lak A., Kre uzer M., M a ch müller A. (2004). Rumen simulation technique study on the interactions of dietary lauric and myristic acid supplementation in suppressing ruminal methanogenesis. Brit. J. Nutr., 92: 689-700.

S r i v a s t a v a V.K., M o w at D.N. (1980). Preservation and processing of whole high moisture shelled corn with ammonia. Can. J. Anim. Sci., 60: 683-688.

S t e ve n s on D.M., We i m e r P.J. (2007). Dominance of Prevotella and low abundance of classical ruminal bacterial species in the bovine rumen revealed by relative quantification real-time PCR. Appl. Microbiol. Biotechnol., 75: 165-174.

Szumacher-Strabel M., Zmora P., Roj E., Stochmal A., Pers-Kamczyc E., Urbańczyk A., Oleszek W., Lechniak D., Cieślak A. (2011). The potential of the wild dog rose (Rosa canina) to mitigate in vitro rumen methane production. J. Anim. Feed Sci., 20: 285-299.

Wa 11 a c e R.J. (1979). Effect of ammonia concentration on the composition, hydrolytic activity and nitrogen metabolism of the microbial flora of the rumen. J. Appl. Microbiol., 47: 443-455.

W o 1 i n M.J. (1960). A theoretical rumen fermentation balance. J. Dairy Sci., 43: 1452-1459.

Yu Z., M o r r i s o n M. (2004). Improved extraction of PCR-quality community DNA from digesta and fecal samples. BioTechniques, 36: 808-812. 
Zhang S., Cheng L., Guo X., Ma C., Guo A., Moons an Y. (2016). Effects of urea supplementation on rumen fermentation characteristics and protozoa population in vitro. J. Appl. Anim. Res., 44: 1-4.

Zijderveld S.M. van, Fonken B., Dijkstra J., Gerrits W.J., Perdok H.B., Fokk in k W., N e w b o ld J.R. (2011). Effects of a combination of feed additives on methane production, diet digestibility, and animal performance in lactating dairy cows. J. Dairy Sci., 94: 1445-1454.

Received: 9 VI 2020

Accepted: 15 X 2020 